\title{
Determine symptoms experienced by the patients with advanced cancer and the factors affecting them
}

\author{
Illeri evre kanser hastalarının semptom deneyimleri \\ ve etkileyen faktörlerin belirlenmesi
}

\author{
Hanife ÖZÇELIK, ${ }^{1}$ Yasemin GÜZEL, ${ }^{2}$ Çiçek FADILOĞLU, ${ }^{3}$ Fatma AKSOY, ${ }^{2}$ Rüçhan USLU² \\ 'Department of Nursing, Niğde University Zübeyde Hanım School of Health Sciences, Niğde \\ ${ }^{2}$ Department of Medical Oncology Unit, Ege University Faculty of Medicine Hospital, Izmir \\ ${ }^{3}$ Ege University Faculty of Nursing, Izmir
}

\section{OBJECTIVES}

The objective of this study is to determine the symptom distributions of patients with advanced cancer as well as the factors affecting these symptoms.

\section{METHODS}

As a descriptive study, it was carried out in the palliative care and medical oncology clinics of a University located in Izmir between 2011-2012 and 164 cancer patients. Research data were obtained by using Edmonton Symptom Assessment Scale (ESAS) and Karnofsky Performance Scale (KPS).

\section{RESULTS}

$52.4 \%$ of the patients participating in the research were male. Total score of ESAS scale was $45.58 \pm 12.41$. A relationship was found between the symptoms of pain and drowsiness and performance levels of the patients $(p<0.05)$. It was determined that total score of ESAS scale was not affected by age, sex, education level and performance level $(\mathrm{p}>0.05)$.

\section{CONCLUSION}

It was determined that total symptom levels of patients were high, they experienced the pain and fatigue symptoms intensively.

Keywords: Advanced cancer patient; symptom intensity.

\section{AMAÇ}

$\mathrm{Bu}$ araștırmanın amacı ileri evre kanser hastaların semptom dağılımlarını ve etkileyen faktörleri belirlemektedir.

\section{GEREÇ VE YÖNTEM}

Tanımlayıcı nitelikte olan bu çalışma, İzmir ilinde bir üniversite hastanesinin palyatif bakım ve tıbbi onkoloji kliniklerinde 2011-2012 tarihleri arasında toplam 164 ileri evre kanser hastası ile yürütüldü. Araştırma verileri Edmonton Semptom Tanılama (ESAS) Ölçeği ve Karnofsky Peformans Skalası (KPS) ile elde edildi.

\section{BULGULAR}

Araştırmaya alınan hastaların \%52.4'ü erkekti. Hastaların $\% 50$ 'sinin performansı önemli derecede yardıma ihtiyaç duyma (KPS puanı 50) düzeyinde idi. ESAS toplam ölçek puan ortalaması $45.58 \pm 12.41$ bulundu. Ağrı ve uyuşukluk semptomları ile hastaların performans düzeyi ile bir ilişki saptandı $(\mathrm{p}<0.05)$. Hastaların ESAS toplam ölçek puanının yaş, cinsiyet, eğitim ve performans düzeyi etkilenmediği belirlendi $(\mathrm{p}>0.05)$.

\section{SONUÇ}

Hastaların toplam semptom düzeylerinin yüksek olduğu, semptom alt boyutlardan ağrı ve yorgunluk semptomlarını yoğun yaşadıkları saptanmıştır.

Anahtar sözcükler: İleri evre kanser hastas1; semptom yoğunluğu. 
Patients with advanced cancer experience many symptoms frequently. Numerous studies in both inpatient and outpatient settings have documented the symptom burden of patients with advanced cancer $^{[1-4]}$ Teunissen et al. detected that the symptom group including 37 different symptoms were experienced by $10 \%$ of the research sample in a study where the patients at the last one or two weeks of the life were included in the $2^{\text {nd }}$ group while the others were included in the 1st group within the scope of a systematic review including 46 different studies on the symptom frequencies of 26.233 cancer patients. ${ }^{[5]}$ However, pain, fatigue, lack of energy, weakness and loss of appetite were detected in more than $50 \%$ of the patients in the $1^{\text {st }}$ group. It was observed that the symptom of weight loss was detected more in the patients in the $2^{\text {nd }}$ group. ${ }^{[5]}$ As the literature shows, patients with advanced cancer suffer from physical and psychological symptoms affecting their lives significantly. Among these symptoms frequently experienced by the patients, pain, fatigue, nausea and vomiting, depression, anxiety, loss of appetite and constipation are primary. ${ }^{[6-8]}$

In a study where the priority of the symptoms caused discomfort and distress in the patients with advanced cancer followed an expert palliative care team, the pain was, according to the patients, detected as the most problematic symptom on its own among the most prioritised five symptoms prior to the palliative care programme. Fatigue, loss of physical function, loss of appetite, nausea and vomiting and pain were included in the first five symptoms. ${ }^{[9]}$ In some cases, fatigue can be experienced more frequently by the patients with advanced cancer. ${ }^{[10,11]}$ Emotional stress is a state frequently experienced by a great majority of the patients who are diagnosed with cancer and are in different periods of treatment. ${ }^{[10,12]}$ However, it was found out that pain and fatigue levels of the cancer patients suffering from considerably uncontrolled emotional stress were higher. ${ }^{[10,13]}$

Symptoms are multi-dimensional, complex and subjective elements that may lead to changes in biological, psychological and cognitive functions of individuals. ${ }^{[14,15]}$ At the same time, they can be affected by numerous factors. Determination of these factors and a proper identification of the effects of these symptoms on the patients are of vital importance in terms of symptom control. As the fundamental objective of providing therapy and patients with advanced cancer is to control symptoms, symptom levels and the factors affecting them should be known. ${ }^{[16]}$

In the studies examining the relationship between sex and symptom, it was determined that female cancer patients experience the symptoms of anxiety and depression more than male patients. ${ }^{[17-20]}$ However, in the literature, there are studies reporting that depression and anxiety are symptoms which do not differ by sexes and are experienced at similar frequencies ${ }^{[17,21]}$ Likewise, while certain studies report that the symptom of nausea is experienced by female patients more frequently than male patients, ${ }^{[22,23]}$ others stated that symptom experiences of male and female patients are not different. ${ }^{[24]}$

Relationship between symptom intensity and age variable among the patients with advanced cancer has been addressed in the literature. In a study, better emotional function, less pain and sleep disorders were detected in aged cancer patients. ${ }^{[22]}$ In another study, it was found out that the patients with advanced cancer under the age of 60 reported higher levels of pain and anxiety in comparison to the patients with advanced cancer above the age of 60 . In the same study, a lower level of appetite was detected among the elderly. ${ }^{[10]}$

As to the relationship between level of education and symptom experience, Jordhoy MS (2001) reported in the study on the factors affecting the life qualities of cancer patients that cancer patients with lower levels of education suffer from less pain in comparison to those with higher levels of education. In the same study, cancer patients with a moderate level of education report that their general well-being is poor in comparison to those having a higher level of education. ${ }^{[22]}$ This study also reveals that married cancer patients has lower social functions than the single ones. However, the life of quality was found statistically significant between married and single patients. ${ }^{[22]}$ 
Relationship between symptom experience and performance levels of individuals is of paramount importance. In the study where qualities of life of patients with advanced cancer were determined, a strong relationship was found between good performance level and quality of life. ${ }^{[25]}$ It was determined in the study that cancer patients with good performance levels have a better quality of life. In another study, a significant relationship was detected between different performance levels of cancer patients and emotional function, fatigue, pain, loss of appetite and constipation. In this study, quality of life scores were found to be good if the performance was good while reduced quality of life was detected when the performance was poor. Physical function, role, social function and general wellbeing were found to be very low in the patients with a Karnofsky performance level below 40 . While minimal change was detected between performance levels of patients and the symptoms of diarrhoea, sleeplessness and dyspnea, it was determined that a regular decrease was observed in the symptom of nausea and vomiting in the patients with a performance level of 70 and below. ${ }^{[22]}$

These intense symptoms experienced by the patients with advanced cancer affect the functional states and qualities of life of individuals in a negative manner. Thus, symptom management constitutes the basis of care. The objective of this research is to determine the symptom distributions of patients with advanced cancer as well as the factors affecting them.

\section{MATERIALS AND METHODS}

Carried out in descriptive pattern in order to determine the symptoms experienced by the patients with advanced cancer and the factors affecting them, this study was conducted in the palliative care and medical oncology clinic of a university hospital found in İzmir between 01.08.2011 and 31.12.2012. 164 patients who are aged 18 and above, are conscious, have no visual impairment and hearing problem, have advanced stage metastases, have Karnofsky Performance Scale levels of 50 and below and accepted to take part in the research were included in the research sample.
Research data were collected through face-toface interviews by using the Patient Identification Form, Edmonton Symptom Assessment System (ESAS) and Karnofsky Performance. ESAS was developed by Bruera E, Kuehn N, Miller M et al. (1991) in order to identify the symptoms of patients with advanced cancer. ${ }^{[26]}$ It includes 9 symptoms including pain, fatigue, nausea, depression, anxiety, drowsiness, loss of appetite, well-being, and dyspnea. There is also an alternative as "other symptom". The scale has a visual analogue or numeric style of design where symptoms can be scored between 0 and 10. 0 means that the symptom is not experienced while 10 means that the symptom is considerably intense. In ESAS calculation, the total score of the scale differs between 0 and 90 . However, if another symptom not included in the scale is selected, an additional scope needs to be supplemented. High score obtained from the scale refers to high symptom level. Validity and reliability of ESAS for Turkish society was tested by Usta Yesilbalkan et al. in 2008 and its Cronbach $\alpha$ level was found to be over $0.70 . .^{[27]}$ In the research, the symptom of "constipation" frequently experienced in palliative care environments was added as other symptom. ESAS consisted of 10 symptoms in total and total score ranged between 0 and 100 .

Karnofsky Performance Scale was used in order to determine the performance levels of patients. While general and functional states of the patients were evaluated with this scale, the scores obtained from the scale ranged between 0 and 100 . While 100 indicates the best functional competence level, 0 refers to death in which there is no functional competence. ${ }^{[28]}$ Having a score of 50 and below $(50,40,30)$ in Karnofsky Performance Scale was used as an inclusion criteria for the study.

\section{Statistical analysis and ethics}

For the research to be conducted, ethics committee of the School of Nursing, hospital and patients were asked for written and oral permission. Numbers, percentages, Mann-Whitney test and Spearman correlation were used in the statistical analysis of the research data. Statistical significance level was used as $\mathrm{p}<0.05$. 


\section{Table 1}

Patients' demographic characteristics

\begin{tabular}{lcc} 
& n & \% \\
\hline Age (mean \pm SD) & \multicolumn{2}{c}{$49.84 \pm 15.23$} \\
Gender & 78 & 47.6 \\
Female & 86 & 52.4 \\
Male & \multicolumn{2}{c}{} \\
Educational level & 9 & 5.5 \\
$\quad$ Nonliterate & 54 & 32.9 \\
Primary school & 22 & 13.4 \\
Secondary school & 46 & 28.0 \\
High school & 33 & 20.1 \\
University & & \\
Marital status & 133 & 81.1 \\
Married & 26 & 15.9 \\
Single & 5 & 3.0 \\
$\quad$ Divorced/separated & & \\
Profession & 12 & 7.3 \\
Worker & 13 & 7.9 \\
Government official & 23 & 14.0 \\
Self employed & 41 & 25.0 \\
Retired & 47 & 28.7 \\
Housewife & 28 & 17.1 \\
Other & 164 & 100.0
\end{tabular}

\section{RESULTS}

While 47.6 of the participants were female patients, $52.4 \%$ of them were male patients. $81.1 \%$ of them were married, $32.9 \%$ of them were graduates of primary school and $28.7 \%$ of them were housewives (Table 1). In terms of the distribution of patients according to the disease characteristics, most of the patients $(72 \%)$ were in the stage IV, $91.5 \%$ of them had metastases and $59.2 \%$ of them were receiving palliative care. $50 \%$ of the patients displayed a performance status requiring a significant amount of help (Karnofsky performance score of 50) (Table 2).

While the patients' total score of ESAS scale is $45.58 \pm 12.41$, their average sub-dimension scores were found out to be $5.56 \pm 2.63$ pain, $6.89 \pm 2.24$ fatigue, $3.64 \pm 3.18$ nausea, $5.09 \pm 2.63$ depression, $4.18 \pm 2.91$ anxiety, $4.23 \pm 3.17$ drowsiness, $5.91 \pm 3.13$ poor appetite, $5.00 \pm 2.72$ poor well-being, $2.24 \pm 3.08$ dyspnea and $2.87 \pm 3.07$ constipation (Table 3 ).

\section{Table 2}

Distribution of factors related to patients' illness ( $n=164)$

\begin{tabular}{lcc} 
& $\mathbf{n}$ & $\mathbf{\%}$ \\
Primary diagnosis & & \\
Gastrointestinal cancer & 38 & 23.2 \\
Osteosarcoma & 24 & 14.6 \\
Genitourinary cancer & 24 & 14.6 \\
Breast cancer & 24 & 14.6 \\
Lung cancer & 12 & 7.3 \\
$\quad$ Other (unknown primary tumor) & 42 & 25.6 \\
Disease duration (years) & & \\
1< & 71 & 43.3 \\
$1-3$ & 59 & 36.0 \\
$4-6$ & 19 & 11.6 \\
$7>$ & 15 & 9.1 \\
Stage of cancer & & \\
Stage III & 46 & 28.0 \\
Stage IV & 118 & 72.0 \\
Karnofsky Performance Score & & \\
50 & 82 & 50.0 \\
40 & 62 & 37.8 \\
30 & 14 & 8.5 \\
20 & 6 & 3.7 \\
\hline
\end{tabular}

Considering the distribution of factors affecting the symptom levels of patients, significant relationships were found between the symptoms of pain and numbness and the performance levels of patients; (Table 4) the symptom of fatigue and age; and the symptom of dyspnea and levels of education of patients $(\mathrm{p}>0.05)$.

\section{DISCUSSION}

In our study, patients with advanced cancer experienced the symptoms at different levels. While the most common symptom was fatigue among patients, it was followed by pain. However, by some studies in the literature, pain was reported to be the most common symptom in patients with advanced cancer. ${ }^{[9,17]}$ On the other hand, some studies reported fatigue as the most frequent symptom in parallel to the results of our research. ${ }^{[1,22]}$ Literature also contains studies in which different symptoms have higher frequencies. ${ }^{[20]}$ Chang et al. detected that cancer patients experienced moderate or severe fatigue. ${ }^{[29]}$ This shows that symptom experience of a 


\section{Table 3}

ESAS total distress score means and subgroup scores at baseline

$\begin{array}{lcc}\text { Symptom } & \text { Means } & \text { SD } \\ \text { ESAS Total Distres Score } & 45.58 & 12.41 \\ \text { Pain } & 5.5 & 2.6 \\ \text { Fatigue } & 6.8 & 2.2 \\ \text { Nausea } & 3.6 & 3.1 \\ \text { Depression } & 5.0 & 2.6 \\ \text { Anxiety } & 4.1 & 2.9 \\ \text { Appetite } & 5.9 & 3.1 \\ \text { Drowsiness } & 4.2 & 3.1 \\ \text { Well-being } & 5.0 & 2.7 \\ \text { Dyspnea } & 2.2 & 3.0 \\ \text { Constipation } & 2.8 & 3.0\end{array}$

SD: Standard deviation; ESAS: Edmonton Symptom Assessment Scale.

patient can be affected by many factors and regular symptom identification is absolutely essential.

In our study, a significant relationship was found between the performance status of patients with advanced cancer and the symptoms of pain and drowsiness. Patients with worse Karnofsky performance statuses suffer from more pain and numbness. In the study conducted by Zimmermann on symptom burden in patients with advanced cancer, it was detected that the patients with poor per- formance statuses experienced fatigue and loss of appetite more frequently along with a deterioration in general well-being. ${ }^{[20]}$ Another study revealed a significant relationship between performance status and the symptoms of fatigue, loss of appetite and dyspnea. ${ }^{[30]}$ In the study where the qualities of life of patients with advanced cancer were determined, a strong relationship was found between good performance level and quality of life. ${ }^{[25]}$ It was reported that cancer patients with good performance levels had better qualities of life. There are also other studies on the relationship between the performance level and quality of life in the literature. ${ }^{[2,31]}$ In cancer patients, the effect of performance level on the symptom frequency and quality of life should certainly be known. This is because of the fact that performance level of a cancer patient is an indicator that may determine the estimated life expectancy in addition to being a value indicating the prognosis. Thus, performance status should be closely followed along with symptom frequency and intensity.

In the present study, a positive significant relationship was found between age and fatigue level. It was determined that the patients became more tired as the age increased. Differently, there are also studies reporting that young patients experience higher levels of fatigue than the old patients

\section{Table 4}

ESAS Total Distress and subgroup symtom scores and performance status

\begin{tabular}{lccccc} 
& \multicolumn{4}{c}{ Performance status } & (Karnofsky \\
\cline { 2 - 4 } & $\mathbf{5 0}$ & $\mathbf{4 0}$ & $\mathbf{3 0}$ & $\mathbf{2 0}$ & $\mathbf{p}$ \\
ESAS Total Distres Score & 76.44 & 82.56 & 97.86 & 115.33 & 0.126 \\
Pain & 73.02 & 88.11 & 90.89 & 134.50 & $\mathbf{0 . 0 0 7}$ \\
Fatigue & 80.86 & 79.01 & 96.11 & 109.25 & 0.311 \\
Nausea & 84.07 & 86.80 & 65.50 & 56.33 & 0.229 \\
Depression & 76.31 & 89.09 & 89.36 & 83.00 & 0.403 \\
Anxiety & 79.43 & 85.07 & 85.46 & 90.92 & 0.855 \\
Appetite & 74.28 & 87.45 & 100.11 & 102.58 & 0.101 \\
Drowsiness & 80.87 & 75.73 & 91.79 & 138.33 & $\mathbf{0 . 0 1 5}$ \\
Well-being & 79.05 & 80.74 & 109.57 & 84.58 & 0.162 \\
Dyspnea & 78.44 & 81.04 & 99.54 & 113.33 & 0.118 \\
Constipation & 84.60 & 77.48 & 81.71 & 107.50 & 0.436
\end{tabular}

ESAS: Edmonton Symptom Assessment Scale. 
in the literature. ${ }^{[25]}$ Distributions of different symptoms are also found in the literature. In a study, it was found out that old cancer patients suffered from loss of appetite while young patients suffered from much more pain. ${ }^{[22]}$ There are studies revealing that qualities of life of the elderly are poor in general population. ${ }^{[32]}$ The effect of age on the quality of life between general elderly population and cancer patients with advanced cancer was explained by comorbid situations resulting from advanced cancer. ${ }^{[32]}$ However, in some studies, higher levels of emotional function, role and social function incompetence among young cancer patients in comparison to the old patients were discussed. The present study reports that the diagnosis of advanced cancer is more traumatic for young patients. ${ }^{[25]}$ These results imply once more that how symptom experience is affected by many factors should be investigated thoroughly in larger populations.

In the literature, researches conducted on the factors affecting symptom experience reported that female cancer patients experienced anxiety and depression more than male patients. ${ }^{[18-20,33]}$ It was determined that sex had an impact on symptom experience. ${ }^{[22]}$ However, a significant relationship could not be found between sex and symptom frequency.

As a conclusion, in the present study where symptom frequencies of patients with advanced cancer and the factors affecting them were examined, it was found out that fatigue and pain were the most common symptoms and symptom scores were generally high in these patients. A relationship was found between low performance level and age. For an effective symptom control to be carried out in the care of a patient with advanced cancer, the results of this study are invaluable for the multidisciplinary teams. However, it is a crystal-clear fact for researchers that symptom experience should be studied more thoroughly in larger populations with regular symptom follow-up.

\section{Disclosures and acknowledgments}

This study were not supported by other organizations and companies. The authors have no conflicts of interest to disclose. The authors thank research team member for their administrative assistance.

\section{REFERENCES}

1 Donnelly S, Walsh D. The symptoms of advanced cancer. Semin Oncol 1995;22(2 Suppl 3):67-72.

2. Walsh D, Donnelly S, Rybicki L. The symptoms of advanced cancer: relationship to age, gender, and performance status in 1,000 patients. Support Care Cancer 2000;8(3):175-9.

3 Walsh D, Rybicki L, Nelson KA, Donnelly S. Symptoms and prognosis in advanced cancer. Support Care Cancer 2002;10(5):385-8.

4. Strasser F, Sweeney C, Willey J, Benisch-Tolley S, Palmer JL, Bruera E. Impact of a half-day multidisciplinary symptom control and palliative care outpatient clinic in a comprehensive cancer center on recommendations, symptom intensity, and patient satisfaction: a retrospective descriptive study. J Pain Symptom Manage 2004;27(6):481-91.

5. Teunissen SC, Wesker W, Kruitwagen C, de Haes HC, Voest EE, de Graeff A. Symptom prevalence in patients with incurable cancer: a systematic review. J Pain Symptom Manage 2007;34(1):94-104.

6. Strömgren AS, Groenvold M, Pedersen L, Olsen AK, Sjogren P. Symptomatology of cancer patients in palliative care: content validation of self-assessment questionnaires against medical records. Eur J Cancer 2002;38(6):788-94.

7. Wilson KG, Chochinov HM, McPherson CJ, LeMay K, Allard P, Chary S, et al. Suffering with advanced cancer. J Clin Oncol 2007;25(13):1691-7.

8. Strömgren AS, Goldschmidt D, Groenvold M, Petersen MA, Jensen PT, Pedersen L, et al. Self-assessment in cancer patients referred to palliative care: a study of feasibility and symptom epidemiology. Cancer 2002;94(2):512-20.

9. Strömgren AS, Sjogren P, Goldschmidt D, Petersen MA, Pedersen L, Groenvold M. Symptom priority and course of symptomatology in specialized palliative care. J Pain Symptom Manage 2006;31(3):199-206.

10. Jones JM, Cohen SR, Zimmermann C, Rodin G. Quality of life and symptom burden in cancer patients admitted to an acute palliative care unit. J Palliat Care 2010 Summer;26(2):94-102.

11. Carlson LE, Angen M, Cullum J, Goodey E, Koopmans J, Lamont L, et al. High levels of untreated distress and fatigue in cancer patients. $\mathrm{Br} \mathrm{J}$ Cancer 2004;90(12):2297-304.

12.De Faye BJ, Wilson KG, Chater S, Viola RA, Hall P. Stress and coping with advanced cancer. Palliat Support Care 2006;4(3):239-49.

13. Rodin G, Walsh A, Zimmermann C, Gagliese L, Jones J, Shepherd FA, et al. The contribution of attachment 
security and social support to depressive symptoms in patients with metastatic cancer. Psychooncology 2007;16(12):1080-91.

14. Guthrie AE, Green CJ, Matzoo ML, Palliative and endof-Life Care. In: Monohan FD, Sands JK, Neighbors M, Marek JF, Gren CF, eds. Medical-Surgical Nursing Health and İllness Perspectives. 8th edition, Mosby Elsiever, Canada 2007:156-76.

15.Abrahm JL. Specialized Care of the terminally III, Cancer, Principles and Practice of Oncology, 7th edition, Lippincott Williams and Wilkins Company, USA 2005:2702-17.

16. Gill A, Chakraborty A, Selby D. What is symptom burden: a qualitative exploration of patient definitions. J Palliat Care 2012 Summer;28(2):83-9.

17. Cheung WY, Le LW, Zimmermann C. Symptom clusters in patients with advanced cancers. Support Care Cancer 2009;17(9):1223-30.

18. Miaskowski C. Gender differences in pain, fatigue, and depression in patients with cancer. J Natl Cancer Inst Monogr 2004;(32):139-43.

19. Strong V, Waters R, Hibberd C, Rush R, Cargill A, Storey $\mathrm{D}$, et al. Emotional distress in cancer patients: the Edinburgh Cancer Centre symptom study. Br J Cancer 2007;96(6):868-74.

20.Zimmermann C, Burman D, Follwell M, Wakimoto K, Seccareccia D, Bryson J, et al. Predictors of symptom severity and response in patients with metastatic cancer. Am J Hosp Palliat Care 2010;27(3):175-81.

21.Riechelmann RP, Krzyzanowska MK, O'Carroll A, Zimmermann C. Symptom and medication profiles among cancer patients attending a palliative care clinic. Support Care Cancer 2007;15(12):1407-12.

22.Jordhøy MS, Fayers P, Loge JH, Saltnes T, Ahlner-Elmqvist M, Kaasa S. Quality of life in advanced cancer patients: the impact of sociodemographic and medical characteristics. Br J Cancer 2001;85(10):1478-85.

23. Rummans TA, Clark MM, Sloan JA, Frost MH, Bostwick JM, Atherton PJ, et al. Impacting quality of life for patients with advanced cancer with a structured multidisciplinary intervention: a randomized controlled trial. J Clin Oncol 2006;24(4):635-42.
24.Cheung WY, Le LW, Gagliese L, Zimmermann C. Age and gender differences in symptom intensity and symptom clusters among patients with metastatic cancer. Support Care Cancer 2011;19(3):417-23.

25.Zimmermann C, Burman D, Swami N, Krzyzanowska MK, Leighl N, Moore M, et al. Determinants of quality of life in patients with advanced cancer. Support Care Cancer 2011;19(5):621-9.

26. Bruera E, Kuehn N, Miller MJ, Selmser P, Macmillan K. The Edmonton Symptom Assessment System (ESAS): a simple method for the assessment of palliative care patients. J Palliat Care 1991 Summer;7(2):6-9.

27. Yesilbalkan OU, Ozkutuk N, Karadakovan A, Turgut T, Kazgan B. Validity and Reliability of the Edmonton Symptom Assessment Scale in Turkish Cancer Patients. Turkish Journal of Cancer 2008;38:262-7.

28. Schag CC, Heinrich RL, Ganz PA. Karnofsky performance status revisited: reliability, validity, and guidelines. J Clin Oncol 1984;2(3):187-93.

29. Chang VT, Hwang SS, Feuerman M, Kasimis BS. Symptom and quality of life survey of medical oncology patients at a veterans affairs medical center: a role for symptom assessment. Cancer 2000;88(5):117583.

30.Chow E, Fung K, Panzarella T, Bezjak A, Danjoux C, Tannock I. A predictive model for survival in metastatic cancer patients attending an outpatient palliative radiotherapy clinic. Int J Radiat Oncol Biol Phys 2002;53(5):1291-302.

31. Snyder CF, Garrett-Mayer E, Brahmer JR, Carducci MA, Pili R, Stearns V, et al. Symptoms, supportive care needs, and function in cancer patients: how are they related? Qual Life Res 2008;17(5):665-77.

32.Fosså SD, Hess SL, Dahl AA, Hjermstad MJ, Veenstra M. Stability of health-related quality of life in the Norwegian general population and impact of chronic morbidity in individuals with and without a cancer diagnosis. Acta Oncol 2007;46(4):452-61.

33.Jordhøy MS, Fayers P, Loge JH, Saltnes T, Ahlner-Elmqvist M, Kaasa S. Quality of life in advanced cancer patients: the impact of sociodemographic and medical characteristics. Br J Cancer 2001;85(10):1478-85. 